10 World Health Organisation. Arterial hypertension. Report of a WHO exper committee on hypertension. WHO Tech Rep Ser 1979:No 628 .

11 National Diabetes Data Group. Classification and diagnosis of diabetes mellitus and other categories of glucose intolerance. Diabetes 1980;28: 1039.57.

12 Rowe DJF, Dawnay A, Watts GF. Microalbuminuria in diabetes mellitus: review and recommendations for the measurement of albumin in urine. Ann Clin Biochem 1990;27:297-312.

13 Eilers R. Notification of final adoption of an international method and standard solution for hemoglobinometry specifications for preparation of standar solution. Am J Clin Pathol 1967;47:212-4.

14 Smith JB, Price AL, Williams RR, Hentschel WM, Sprowell W, Hunt SC et al. A reproducible sodium-lithium countertransport assay: the outcome of changing key laboratory parameters. Clin Chim Acto 1982:122:327-35

15 Laurenzi M, Trevisan M. Sodium-lithium countertransport and blood pressure: the Gubbio population study. Hypertension 1989;13:408-15.

16 Turner ST, Weidman WH, Michels VV, Reed TJ, Ornon CL, Fuller T, et at. Distribution of sodium-lithium countertransport and blood pressure in Distribution of sodium-lithium countertransport and blow

17 Trevisan M, Ostrow D, Cooper R, Liu K, Sparks S, Stamler J. Methodological assessment of assays for red cell sodium concentration and sodium dependent lithium efflux. Clin Chim Acta 1981;116:319-29.

18 Lewitter FI, Canessa M. Red cell sodium transport studies in adult twin Am $\mathcal{Y}$ Hum Genet 1985; suppl 36:172S.

19 Halkin A, Benjamin A, Doktor HS, Todd SD, Viberti G, Ritter JM. Vascula responsiveness and cation exchange in insulin-dependent diabetes. Clin $S_{C}$ 1991;81:223-32.

20 Smith JB, Weinberger MH, Wade MB. Is the correlation between sodium lithium countertransport and sodium-potasium cotransport an artifact of methodolog? Clin Chim titu 1986:157:317-20.

21 Rutherford PA, Thomas TH, Wilkinson R. Increased erythrocyte sedium lithium countertransport activity in essential hypertension is due to an increased affinity for extracellular sodium. Clin Sci 1990; 79:365-9.

22 Canessa $\mathrm{M}$. Kinetic properties of $\mathrm{Na}^{\prime} / \mathrm{H}^{\prime}$ exchange and $\mathrm{Li}^{\prime} / \mathrm{Na}^{\prime}, \mathrm{Na}{ }^{\prime} / \mathrm{Na}$ and $\mathrm{Na}^{\prime} / \mathrm{Li}^{\prime}$ exchanges of human red cells. Methods Enzymol 1989:173 $176-91$

23 Rutherford PA, Thomas TH, Wilkinson R. Erythrocyte sodium-lithium countertransport: clinically useful, pathophysiologically instructive or jus phenomenology? Clin Sci 1992;82:341-52.

24 Foyle WJ, Drury PL. Reductions in $\mathrm{Li}^{\prime}-\mathrm{Na}^{\prime}$ countertransport by physiological levels of insulin in vivo. I Hypertens 1991:9:713-7.

25 Schicken RM, Eaves LJ, Hewitt JK, Mosteller M, Bodurtha JN, Moskowitz WB, et al. Univariate genetic analysis of blood pressure in children (the medical college of Virginia twin study). A $m \mathcal{F}$ Cardiol 1989;64:1333-7.

26 Kaas Ibsen K, Rotne H. Hougaard P. Blood pressure in children with diabetes mellitus. Actu Paediatr Scand 1983:72:191-6.

27 Tarn AC. Drury PL. Blood pressure in children, adolescents and young adults with type 1 (insulin-dependent) diabetes. Diabetologia 1986:29:275-81.

28 Mathiesen ER, Hilsted J, Feldt-Rasmussen B, Bonde-Petersen F, Chistensen $\mathrm{NJ}$, Parving HH. The effect of metabolic control on hemodynamics in shortterm insulin-dependent diabetic patients. Diabetes 1985;34:1301-5.

29 Ferrari P, Weidmann P. Insulin, insulin sensitivity and hypertension f Hypertens 1990;8:+91-500

\title{
Impact of HIV infection on mortality in young men in a London health authority
}

\author{
John Aldous, Matthew Hickman, Antony Ellam, Brian Gazzard, Sally Hargreaves
}

Abstract

Objective-To determine the number of deaths attributable to HIV infection among men aged 15-64 in a geographically defined population in the United Kingdom.

Design-Retrospective review of death certificates and linkage with local and national HIV and AIDS surveillance data.

Setting-Riverside District Health Authority, London.

Main outcome measures-Numbers of deaths attributed to HIV infection in male residents of Riverside aged 15-64 and 15-44 over a six month period. Proportion of attributed deaths were (i) identified from death certificates by the Office of Population Censuses and Surveys as being due to HIV infection and (ii) reported as cases of AIDS or HIV related deaths to the Public Health Laboratory Service Communicable Disease Surveillance Centre.

Results -34 of 213 (16\%) deaths in men aged 15-64 and 27 of $69(39 \%)$ deaths in men aged 15-44 were attributed to HIV infection. Six of $33(18 \%)$ attributed deaths were identified by the Office of Population Censuses and Surveys and 32/34 (94\%) were reported to the Communicable Disease Surveillance Centre.

Conclusions - HIV infection was the leading cause of death in male residents of Riverside aged 15-44 and the third commonest cause of death in those aged 15-64. Most individuals dying of known HIV infection were reported to the Communicable Disease Surveillance Centre but identification of the true cause of death from the process of death certification was poor. Measures to improve the certification of HIV and AIDS or the use of AIDS surveillance information correctly to code the cause of death needs to be considered to ensure that the true impact of HIV infection is reflected in routine mortality statistics.

Dr J Aldous, Department of

Public Health, District

Headquarters, Ealing

Hospital, St Bernard's

Wing, Southall, Middlesex UB1 3EU.

$B M \mathcal{F} 1992 ; 305: 219-21$ and in some cities in the United States' and Africa ${ }^{2}$ it is the leading cause of death in young adult men.

Information on mortality from HIV infection in $\vec{\varphi}$ England and Wales is obtained from two main sources: $N$ the Office of Population Censuses and Surveys, which compiles mortality statistics derived from information on death certificates, and the Public Health Laboratory Service Communicable Disease Surveillance Centre, which runs the national AIDS surveillance system. Concerns have been expressed that information from these two sources may considerably underestimate the mortality from HIV infection. There are two main reasons. Firstly, HIV infection or AIDS is frequently not recorded on death certificates owing to concerns over confidentiality arising from the public nature of these documents. ${ }^{3}$ Secondly, although AIDS surveillance can provide useful information on mortality in people diagnosed as AIDS cases (subject to a small degree of underreporting of AIDS cases and some delays in identifying deaths in reported cases) ${ }^{+5}$ the number of infected people who die before developing or being diagnosed as having an AIDS indicator disease $N$ is not known.

This study was undertaken to determine the number of deaths attributable to HIV infection in males aged between 15 and 64 resident in Riverside Health Authority, London.

\section{Subjects and methods}

Riverside Health Authority covers an area of inner London with a high prevalence of HIV infection." Specialist care for people with HIV infection is provided at several centres, which together have reported around $25 \%$ of the AIDS cases in England and Wales.

Copies of the death certificates of residents of the health authority and of homeless people dying within 8 the district are routinely sent to the public health department and entered on to a computerised mortality register. A previous study had established a local $\rightleftharpoons$ database of people known to be infected with HIV (HIV database). ${ }^{*}$ Surnames on this database were anonymised by soundex code. ${ }^{4}$

The mortality register was used to identify all deaths 


\begin{tabular}{|c|c|c|c|c|c|c|c|c|c|}
\hline & Neoplasms & $\begin{array}{c}\text { Ischaemic } \\
\text { heart } \\
\text { disease }\end{array}$ & HIV & Accident ${ }^{\star}$ & Other & $\begin{array}{c}\text { Liver } \\
\text { disease }\end{array}$ & $\begin{array}{l}\text { Other } \\
\text { vascular } \\
\text { disease }\end{array}$ & Suicide & Total \\
\hline No $(\%)$ of deaths & $45(21 \cdot 1)$ & $37(17 \cdot 4)$ & $34(16.0)$ & $30(14 \cdot 1)$ & $24(11 \cdot 3)$ & $18(8 \cdot 5)$ & $17(8 \cdot 0)$ & $8(3 \cdot 8)$ & $213(100 \cdot 0)$ \\
\hline
\end{tabular}

^Accident includes all external injury undetermined whether accidentally or purposely inflicted.

TABLE II - Underlying causes of death recorded on death certificates in 34 males aged 15-64 whose deaths were attributed to HIV infection

\begin{tabular}{|c|c|}
\hline Underlying cause of death & $\begin{array}{c}\text { No(\%) } \\
\text { of subjects }\end{array}$ \\
\hline $\begin{array}{l}\text { AIDS } \\
\text { AIDS indicator disease } \\
\text { Other infectious disease } \\
\text { Neoplasms } \\
\text { Accident, suicide, or undetermined injury } \\
\text { Other }\end{array}$ & $\begin{array}{rr}2 & (5 \cdot 9) \\
3 & (8 \cdot 8) \\
24 & (70 \cdot 6) \\
3 & (8 \cdot 8) \\
1 & (2 \cdot 9) \\
1 & (2 \cdot 9)\end{array}$ \\
\hline Total & $34(100 \cdot 0)$ \\
\hline
\end{tabular}

TABLE III-Causes of death in 69 males aged 15-44

\begin{tabular}{cccccccc}
\hline & HIV & Accident* & Other & Neoplasms & Suicide & $\begin{array}{c}\text { Liver } \\
\text { disease }\end{array}$ & Total \\
\hline No (\%) of deaths & $27(39 \cdot 1)$ & $18(26 \cdot 1)$ & $9(13 \cdot 0)$ & $5(7 \cdot 2)$ & $5(7 \cdot 2)$ & $5(7 \cdot 2)$ & $69(100 \cdot 0)$ \\
\hline
\end{tabular}

*Accident includes all external injury undetermined whether accidentally or purposely inflicted.

occurring over a six month period in 1990 in males aged 15-64. A death was assumed to be due to HIV infection if one of the following conditions was met: $(a) \mathrm{HIV}$, AIDS, or an AIDS indicator disease ${ }^{10}$ (without any other cause of immunodeficiency) recorded as a cause of death; $(b)$ the record on the mortality register matched one on the HIV database for both soundex code and date of birth; (c) the death had occurred at a hospice known to care exclusively for people with HIV infection; $(d)$ the record on the mortality register matched one on the Communicable Disease Surveillance Centre's national database of AIDS cases and HIV related deaths (as at December 1990) for both soundex code and date of birth.

All deaths in males aged 15-64 were grouped by cause of death, and potential years of life lost ${ }^{11}$ were calculated by using the formula: potential years of life lost $=\Sigma(64.5-y)$, where $y=$ age at death in years. Deaths attributed to HIV were cross checked with the Office of Population Censuses and Surveys in December 1990 to determine how many had been coded as being due to AIDS or HIV infection. The attributed deaths were also cross checked with the Communicable Disease Surveillance Centre in December 1991 to determine how many had been reported as AIDS cases and HIV related deaths.

\section{Results}

A total of 213 deaths in male residents and homeless men aged 15-64 were recorded on the mortality register for the six month period. Thirty four $(16 \%)$ were attributed to HIV infection by our criteria (table I). Only five $(15 \%)$ of these could be identified from the cause of death stated on the death certificate (table II). A further $23(68 \%)$ were identified from the HIV register, two $(6 \%)$ because the death occurred at an AIDS hospice, and the remainder-four (12\%)solely through reports held at the Communicable Disease Surveillance Centre. Overall 32 (94\%) of the 34 deaths attributed to HIV occurred in men who had been reported by December 1991 to the Communicable Disease Surveillance Centre as cases of AIDS or as HIV related deaths. Thirty three deaths attributed to HIV infection were cross checked with the Office of Population Censuses and Surveys in December 1990.
Six $(18 \%)$ had been coded by the office as being due to HIV or AIDS - two (6\%) because HIV or AIDS had been stated on the death certificate and four $(12 \%)$ because the confidential reporting system had been used and subsequent correspondence with the clinician had disclosed that the death was due to HIV infection. In a further death the confidential reporting system had been used but the Office of Population Censuses and Surveys had yet to receive a reply from the clinician concerned.

There were 69 deaths in men aged 15-44, 27 (39\%) of which were attributed to HIV infection (table III). The years of potential life lost from the major causes of death in men aged 15-64 are shown in table IV.

TABLE IV-Potential years of life lost to age 65 by cause of death in 213 males aged 15-64

\begin{tabular}{lc}
\hline Cause of death & $\begin{array}{c}\text { Potential years } \\
\text { of life lost } \\
(\text { No }(\%))\end{array}$ \\
\hline HIV & $930(28 \cdot 0)$ \\
Accidents and injuries undetermined whether & $748(22 \cdot 6)$ \\
accidentally or purposely inflicted & $459(13 \cdot 8)$ \\
Neoplasms & $287(8 \cdot 7)$ \\
Ischaemic heart disease & $251(7 \cdot 6)$ \\
Liver disease & $187(5 \cdot 6)$ \\
Suicide & $139(4 \cdot 2)$ \\
Other vascular disease & $315(9 \cdot 5)$ \\
Other & $3316(100 \cdot 0)$ \\
\hline Total & \\
\hline
\end{tabular}

\section{Discussion}

During the six months of the study HIV infection was identified as the leading cause of death in Riverside in males aged 15-44, the third commonest cause of death in males aged 15-64, and the cause of the greatest loss of potential years of life for males aged 15-64.

Three possible biases need to be discussed. Firstly, although it is reasonable to assume that HIV infection was the underlying cause of death in men identified as AIDS cases through reports held at the Communicable Disease Surveillance Centre or where the cause of death recorded on the death certificate was AIDS or an AIDS indicator disease, some doubt might exist over the two deaths that were attributed solely on the basis of the HIV register. People infected with HIV may, of course, die of causes unrelated to their infection. However, we think that the assumption that HIV infection was the underlying cause of these deaths is reasonable as both subjects had certified causes of death which were consistent with an underlying HIV infection.

Secondly, owing to delayed registration and forwarding of all death certificates we may not have received notice of all the relevant deaths. The number missed in this way is likely to be negligible as all death certificates received up to one year after the end of the study period were included. Thirdly, some deaths due to HIV may not have been identified because the infection was not recognised before death ${ }^{12}$ or because the HIV and AIDS surveillance data used were incomplete. The magnitude of this bias is difficult to estimate. If significant, our results may considerably underestimate the number and proportion of deaths associated with HIV infection.

This study is the first in the United Kingdom 
accurately to assess the mortality from known HIV infection in a geographically defined population. The results underline the significance of the epidemic in Riverside, and it is likely that similar results would be found in other areas of the United Kingdom with a high prevalence of HIV infection.

After a long term decline death rates among young men in England and Wales have increased in most years since $1985 . .^{13}$ The reasons are not clear, and in particular it is not certain how much of the increase is due to HIV infection. ${ }^{1+15}$ McCormick has suggested that between $8 \%$ and $30 \%$ of deaths associated with HIV infection in young single men are not recognised through death certification and national surveillance. ${ }^{15}$ This study showed that in Riverside $94 \%$ of people dying of known HIV infection could be identified through national surveillance. The number of in dividuals dying before a diagnosis of HIV infection was made cannot be estimated from this study.

The study confirms that HIV or AIDS is rarely recorded on death certificates and that the confidential reporting system to the Office of Population Censuses and Surveys is infrequently used. As a result routine mortality statistics from the Office of Population Censuses and Surveys on the causes of death in young men are likely to be of limited value in areas with a significant mortality from HIV infection. This problem needs to be addressed. One solution would be to improve the recording of HIV and AIDS on death certificates - for example, by making information on the certified cause of death confidential. Alternatively, information from the national AIDS surveillance systems could be shared with the Office of Population
Censuses and Surveys to enable them correctly to code deaths due to HIV infection and thus ensure that mortality statistics accurately reflect the impact of HIV infection.

We thank Dr John Porter, Dr Noel Gill, Ms Choloud Porter, and Dr Anna McCormick for help and support.

1 Centers for Disease Control. Mortality attributable to HIV infection/AIDSUnited States, 1981-1990. MMWR 1991;40:41-4.

2 DeCock KM, Barrere B, Diaby L, Lafontaine MF, Gnaore E, Porter A, et al. AIDS - the leading cause of adult death in the west African city of Abidjan Ivory Coast. Science 1990;249:793-6.

3 McCormick A. Trends in the mortality statistics in England and Wales with particular reference to AIDS from 1984 to April 1987. BMJ 1988;296: 1289-92.

4 Evans GE, Gill ON, Emslie JAN. Completeness of reporting of AIDS cases. BMF 1991;302:1351-2.

5 Bobby JJ, Spencer PD, Wyatt JC, Farmer RD'T. AIDS deaths in the UK how complete are the figures? Public Health 1988;102:519-24.

6 Hickman M, Aldous J, Durman L, Ellam A, Porter J, Shanson S. HIV seroprevalence in a defined London population. Lancet 1990;336:1328-9.

7 PHLS AIDS Centre-Communicable Disease Surveillance Centre, and Communicable Diseases (Scotland) Unit. Quarterly surveillance tables. No 11. London: PHLS, 1991

8 Hickman M, Aldous J, Porter J, Durman L. HIV surveillance in districts: the need for audit. BMF 1991;302:1376.

9 Fenna D. Phonetic reduction of names. Comput Methods Programs Biomed 1984;19:31-6.

10 Centers for Disease Control. Revision of the CDC surveillance case definition for acquired immunodeficiency syndrome. MMWR 1987;36 (suppl 1):3-15. 11 Centers for Disease Control. Premature mortality in the United States. MMWR 1986;35(suppl 2):1-1

12 McCormick A. Unrecognised HIV related deaths. BMf 1991;302:1365-7.

13 Department of Health and Social Security. On the state of the public health for the year 1989. London: HMSO, 1990.

14 McCormick A. Estimating the size of the HIV epidemic by using mortality data. Philos Trans R Soc Lond (Biol) 1989;325:163-73.

15 McCormick A. Excess mortality associated with the HIV epidemic in England and Wales. BMF 1991;302:1375-6.

\title{
Evidence of transmission of tuberculosis by DNA fingerprinting
}

\author{
Peter Godfrey-Faussett, Philip R Mortimer, P Anthony Jenkins, Neil G Stoker
}

\section{Abstract}

Objective-To determine whether a subject who had died of tuberculous meningitis had been infected by a neighbour.

Design-Retrospective comparison of isolates of Mycobacterium tuberculosis from the two cases and from 10 controls by DNA fingerprinting.

Setting-Public Health Service Reference Laboratory for Mycobacteria and bacterial molecular genetics unit of the London School of Hygiene and Tropical Medicine.

Subjects-Deceased and neighbour; 10 controls from the same city, from whom isolates had been collected over three months before the subject's death.

Main outcome measures-Identity and similarity values $\left(S_{A B}\right)$ between fingerprint patterns from different isolates obtained by hybridisation of restriction fragments produced by $P$ vull with a probe from the insertion element IS6110/986, present in multiple copies throughout the genome of $M$ tuberculosis.

Results-Isolates from the two cases under investigation had identical fingerprints whereas those from the controls were all distinct. Two clusters of isolates with a similarity coefficient $>0.25$ were identified: in one, four out of five patients were born in the midlands (the birth place of the fifth was not known) and in the other all three patients were born in the Indian subcontinent

Conclusions - The data are consistent with, but do not prove, transmission of tuberculosis from the neighbour to the deceased. Geographical separation of the pools of infection may have led to the evolution of distinct clusters of fingerprint patterns. DNA fingerprinting of $M$ tuberculosis is a powerful new tool for study of the epidemiology and pathogenesis of tuberculosis.

\section{Introduction}

The discovery of an DNA insertion element (variously named IS6110 or IS986) that is present as multiple copies scattered throughout the genome of 윽 Mycobacterium tuberculosis ${ }^{1}$ has allowed the develop- $N$ ment of DNA fingerprinting techniques for identifying $D$ different isolates. ${ }^{23}$ Although this insertion element must be mobile, the rate of change of the DNA fingerprint seems sufficiently slow to give these methods great epidemiological power.

After the death of a patient from tuberculous meningitis we were asked to help to determine whether the infection was likely to have been transmitted from a person living in the vicinity in whom cavitary, pulmonary disease had been diagnosed six months previously but who had not complied fully with treatment despite having been advised of the risk of infection. We believe that this is the first report of the use of this method in a forensic or public health investigation in the United Kingdom.

\section{Methods}

Isolates of $M$ tuberculosis were available from a postmortem meningeal biopsy specimen and from sputum cultured from the neighbour. Ten further isolates from the same city, collected over the three 